\title{
A Functional Analysis of 2013 Australian Member of Parliament and Prime Minister Debates
}

\author{
William L. Benoit ${ }^{1}$, Jennifer M. Benoit-Bryan ${ }^{2}$ \\ ${ }^{1}$ Ohio University, Athens, OH 45701, USA \\ ${ }^{2}$ Research Analyst, SloverLinett, Chicago, IL 60614,USA \\ Correspondence: William L. Benoit, Ohio University, Athens, OH 45701, USA
}

Received: April 2, 2015 Accepted: April 18, 2015 Online Published: June 15, 2015

doi:10.11114/smc.v3i2.882 URL: http://dx.doi.org/10.11114/smc.v3i2.882

\begin{abstract}
Kevin Rudd (Labor) engaged in two election debates in 2013: first for his seat in Parliament (Griffith) and then for Prime Minister. In seeking re-election to his Griffith seat he was challenged by Bill Glasson (Liberal), Geoff Ebbs (Green), and Karen Hunter (Palmer United). He faced Tony Abbott (Liberal) in the PM Debate. This study content analyses these two debates: an August 6, 2013 Member of Parliament debate and an August 11, 2013 Prime Minister debate. Acclaims were more common in these two debates than attacks; defenses were the least common function. Statements about policy outnumbered those on policy. In each debate, when the candidates discussed record in office (past deeds), the incumbent acclaimed more and attacked less than the challenger. More acclaims and fewer attacks addressed general goals and ideals.
\end{abstract}

Keywords: Australia, prime minister, debate, functions, topics, incumbency

\section{Introduction}

Many democratic countries have employed political leaders debates to help voters decide how to cast their votes, including Australia, Canada, Egypt, France, Germany, Ghana, Greece, Holland, Iran, Israel, Mauritania, New Zealand, Nigeria, Scotland, South Korea, Spain, Sweden, Poland, Taiwan, the Ukraine, and the United States (see, e.g., Coleman, 2000). Televised debates are an important medium in modern campaigns because they have advantages over other message forms. First, debates offer information to voters: Televised debates are much longer than other common messages forms, such as TV spots - and some countries, like the UK, restrict television advertising: candidates are prohibited from running television spots; "major parties are allocated rationed blocks of free time for. . party election broadcasts (PEBs) during official campaign periods" (Scammell \& Langer, 2006, p. 65). Second, the nature of campaign debates, which allows voters to hear alternatively from leading candidates, helps voters compare and contrast the candidates' character and issue positions. Third, debate rules typically do not allow candidates to bring notes to the debates. Candidates must speak extemporaneously, and despite their preparation for debates, they may have to provide spur of the moment answers to unexpected questions or comments from opponents. This means that debate viewers may get a more candid view of each candidate than occurs from heavily scripted messages such as stump speeches or TV spots (Schrott, 1990). Debates generate media attention as well political discussion among citizens concerning the candidates and their policies, which broadens their potential influence. Candidates also benefit from the free media exposure provided by televised debates.

Televised election debates can have significant effects on their audiences. Benoit, Hansen, and Verser (2003) applied meta-analysis to research on American presidential debates: These messages increased issue knowledge, affected perceptions of the candidates' character, and altered vote choice (of course, not every viewer's knowledge is increased or attitudes changed, but the observed effects are significant). Studies of political leaders debates in other countries also document effects from viewing debates. Lanoue (1991) found that the Canadian leadership debates in 1984 had influenced the voting behavior of viewers. Blais and Boyer (1996) reported that the Canadian debates of 1988 altered vote choice and voters' perceptions. Maier and Faas (2003) found that the German debates of 2002 influenced candidates' images. Blais, Gidengil, Nadeau, and Nevitte (2003) argued that the Canadian debates in 2003 were "critical in the Conservative surge" (p. 49). Blais and Perrella (2008) found effects from debates in America and Canada. Those who watched the 2010 UK debates learned about the policies of the parties and the character of the party leaders 
(Blumler, 2001). So, much research has established that televised political leaders' debates have significant effects on viewers.

Debates have the potential to increase political efficacy and promote civic engagement (Chaffee, 1978). Because political election debates tend to attract large audiences - e.g., half of eligible Canadian voters watched the 1979 debate (LeDuc \& Price, 1985), 59\% watched the Israeli debate in 1996 (Blum-Kulka \& Liebes, 2000), and 65\% watched one of the German chancellor debates in 2002 (Faas \& Maier, 2004) - they have a substantial potential to inform and influence voters.

One problem is a lack of information about political election debates for offices other than prime minister (or chancellor, or president). A search of the literature located no research on debates for seats in parliament. Of course, one cannot contest the office of prime minister unless one holds a seat in parliament. This study compares a debate for the Griffith seat in the Australian parliament with a prime minister debate from the same election.

Galasinski (1998) looked at rule breaking in the 1995 Polish debates. Coleman's (2000) volume compiles essays about international debate; these chapters tend to be historical or conceptual pieces. Gomard and Krogstad (2001) edited a book on discourse and gender in debates held in Denmark, Finland, Norway, and Sweden. Matsaganis and Weingarten (2001) investigated a 2000 Greek prime minister debate, examining issues, strategy, and style. Khang (2008) applied Kaid and Johnston's (2001) video-style to South Korean and U.S. debates. Baker and Norpoth (1981) concluded that the 1972 West German debates focused more on issues than ethics (character). They noted that the candidates supporting the government tended to defend their record while opposition party candidates were prone to attack the government's record. Coleman (2011) includes analyses of media coverage of, and blogs about, the 2010 UK debates.

Benoit's (2007) Functional Theory, which argues that candidates for elective office use three functions (acclaims or positive statements, attacks or criticisms of opponents, and defenses or refutations of attacks) on two topics (policy or issues, character or personality) to court voters. Research revealed that acclaims tend to be more common than attacks, which are in turn more frequent than defenses (Benoit, 2014). Further, incumbents are prone to acclaim more and attack less than challengers - and particularly so when the candidates discuss past deeds or record in office. Candidates in political leaders debates discuss policy (problems amenable to governmental action and proposals for governmental action) more frequently than character (personality and traits of candidates).

\section{Method}

The Functional Theory of Political Campaign Discourse (Benoit, 2007, 2014) posits that candidates seek to appear preferable to other candidates to win elections. Three functions of messages can foster the impression that a candidate is preferable to opponents: acclaims, attacks, and defenses. An acclaim is a positive statement about the qualities, accomplishments, or desirable proposals of a candidate, an attack identifies a drawback of an opponent (or an opponent's political party), and a defense is a statement that attempt to refute an attack leveled against the candidate. These three functions work together in an informal variant of cost-benefit analysis: Functional Theory does not assume that voters assign numerical values to acclaims, attacks, or defenses, or that citizens combine these three functions mathematically. Nevertheless, acclaims tend to increase a candidate's apparent benefits, attacks are inclined to increase an opponent's perceived costs, and defenses can reduce a candidate's alleged costs. Nor does this approach assume that every voter will interpret a given statement in the same way. For example, calling a candidate "conservative" would be considered a desirable attribute by some (an acclaim) but undesirable by others (an attack). Reinemann and Maurer (2005) found that use of acclaims in German political leaders debates generated general support in the audience whereas attacks, statements of fact, and political plans tended to polarize the audience.

Functional Theory posits that candidates in political campaigns discuss two topics as they attempt to persuade voters of their preferability to other candidates: policy and character. Fundamentally, policy reflects what we do and character is who we are. Policy utterances, which are often called "issues," concern problems and proposals for alleviating those problems; character comments address the qualifications and personalities of the candidates. Research established that American presidential candidates who discussed policy more, and character less, than their opponents were significantly more likely to win elections (Benoit, 2003). These topics are conceptually discrete but we acknowledge that some overlap exists. For example, a candidate who acclaims his or her character as caring might be assumed to favor policies that help the homeless.

Both of these topics are further divided into three components. When addressing policy, political candidates can acclaim or attack in three areas: past deeds, future plans, or general goals. Past deeds refer to the governmental actions taken by the candidate or on behalf of the candidate or the record in office (these facilitate retrospective voting; see Benoit, 2006). Future plans are policies that the candidate will pursue if elected or re-elected: specific campaign promises. Future plans propose the means to accomplish an end. General goals are less specific than future plans and do not contain information about the candidates' specific proposals, stressing ends rather than means (Future Plans and General Goals 
both relate to prospective voting).

Character, frequently referred to as "image," includes three categories: personal qualities, leadership ability, and ideals. Personal qualities are characteristics of candidates such as honesty, courage, and decency. Leadership ability refers to the candidates' abilities to administer the government. Often statements concerning leadership relate to the candidates' experience in elective office. Those who have not served in such offices sometimes use other managerial experiences (e.g., success in business) to acclaim leadership ability. Ideals represent the candidates' basic principles or values. Examples of acclaims and attacks on the forms of policy and of character are available in Benoit (2014).

Based on Functional Theory (Benoit, 2007) and research on political leaders' debates in particular (Benoit, 2014), we test six hypotheses and answer three research questions on these two debates. Initially, Functional Theory explains that acclaims have no drawbacks, whereas attacks have a single drawback: Voters say they dislike mudslinging, which could result in a backlash against candidates who attack in a debate (Merritt, 1984; Stewart, 1975). Defenses, in contrast, have three potential limitations. The candidate must identify an attack to refute it, which could inform or remind some voters of a potential liability of the defending candidate. Second, attacks usually occur on a candidate's weak points, which means a defense usually takes a candidate "off message." Finally, the defensive posture is reactive rather than proactive, which could be perceived unfavorably by voters. Accordingly, Functional Theory predicts that:

H1: Candidates use acclaims more frequently than attacks; defenses occur least often.

Although some people believe that candidates are role models (foregrounding character), political leaders formulate and implement policy. Prime ministers have important policy responsibilities, so Functional Theory would predict that:

$\mathrm{H} 2$ : Candidates discuss policy more often than character.

Incumbent candidates running for re-election have an important resource that is rarely available for challengers: a record of service in the office sought. Challengers often have service in other governmental offices, but it is not the same as experience as president or prime minister. For example, in the United States in 2004, John Kerry had served as a Senator. However, Senators do not implement the bills they introduce and pass; the Senate ratifies treaties and confirms appointments of ambassadors, but Senators do not have the same kinds of foreign policy experience that incumbent presidents have. Similarly, challengers may have experience as state governors, as was the case with Bill Clinton in 1992 and George W. Bush in 2000, but again that is not quite the same as experience as a country's leader. Functional Theory argues that incumbents and challengers both engage in acclaims and attacks - but that incumbents are more likely to acclaim, and less likely to attack, than challengers. This relationship is particularly important when they discuss their records in office: Incumbents are more likely to acclaim their own record, whereas challengers are prone to attack the incumbent's record. Hence, we offer two predictions:

H3: Incumbent candidates use acclaims more, and attacks less, than challengers.

H4: Incumbent candidates use past deeds more for acclaims, and less for attacks, than challengers.

The two research questions concern the relative frequency of the three forms of policy and of the three forms of character.

RQ1. What is the distribution of the three forms of policy?

RQ2. What is the distribution of the three forms of character?

The next two predictions concern a form of policy (general goals) and of character (ideals). Candidates generally find it easier to acclaim than to attack using these utterances. Who opposes strengthening national defense (a general goal) or equality (an ideal)?

H5: Candidates use general goals more frequently to acclaim than to attack.

H6: Candidates use ideals used more frequently to acclaim than to attack.

The data on these hypotheses from analysis of these debates will enhance our understanding of the nature of televised campaign debates.

Cohen's kappa was employed to check reliability of the data. About $10 \%$ of the transcripts; including portions sections from both debates, were used to calculate inter-coder reliability. Kappa was .94 for functions, .84 for topics, .89 for forms of policy, and .84 for forms of character. Landis and Koch (1977) indicate that kappas of .81 or higher reflect almost perfect agreement between coders, so these data have good reliability.

Kevin Rudd became Prime Minister when the Labor Party won the 2007 Australian federal election. Three years later, his party became dissatisfied with his leadership; he resigned and Julia Gilland ran unopposed for the leadership of the Labor Party in June. When this vote occurred she became Prime Minister because Labor controlled the Australian parliament. The 2010 federal elections in August resulted in a hung parliament but Gilland was able to continue serving 
as Prime Minister by forming a coalition government. However, in June of 2013 Kevin Rudd contested her leadership in a Labor Party caucus, a vote he won, resuming his role as leader of the Labor Party and once again becoming Prime Minister. The Labor Party appeared to have revolving leadership. Rudd participated in a debate for his seat in parliament (Griffith) with Bill Glasson (Liberal), Geoff Ebbs (Green), and Karen Hunter (Palmer United). Rudd then faced Tony Abbott (Liberal) in a Prime Minister debate. After the prime minister debate in September a federal election was held and Rudd retained his Griffith seat but the Liberal Party defeated Labor putting Tony Abbott in the Prime Minister's office. This study applies Functional Theory to both debates in which Rudd participated in 2013.

\section{Results}

The first hypothesis predicted that the candidates in this debate would use acclaims more often than attacks and attacks more frequently than defenses. In the MP debate, candidates used acclaims (60\%) more than attacks (34\%) or defenses (6\%). Similarly, in the PM debate, the candidates also acclaimed (64\%) more than they attacked (28\%) or defended $(9 \%)$. For example, Abbott explained that "Our carbon tax cuts are designed to increase jobs, to improve job security and help people with their cost of living. Abolishing the carbon tax will mean a $\$ 550$ a year saving for the average household." This policy proposal is offered as a family-friendly idea. Rudd touted his accomplishments for families, noting that "One measure we've taken is to increase the childcare rebate from 30 to 50 per cent, another measure we've taken is to ensure that kids who are at school, supporting their families, receive a School Kids' Bonus." These utterances illustrate acclaims.

These candidates in these debates also attacked one another. Rudd illustrated this function when he criticized his opponent's record, declaring that when he served as Health Minister Mr. Abbott "took \$1 billion out of hospital funding." Abbott criticized the Prime Minister, charging that "There has been an enormous amount of waste over the last six years. Mr. Rudd talks about keeping Australia out of a recession but spending money on pink batts that caught fire in people's roofs or spending money on over-priced school halls that double what would have been a fair market value." These moves could easily be seen as wasteful spending by voters.

Candidates also employed defense in these Australian election debates. For instance, Rudd responded to charges that his government was spending too much:

Expenditure now as a proportion of GDP is a little greater than it was on the average for the Howard Government period, about 24 per cent of GDP under them, about 25 per cent under us, and the reason for that difference was investing in our country's future to ensure that we did not allow the country to fall into recession.

This utterance attempts two defenses: minimizing the difference in spending and justifying spending as a means to avoid recession. Abbott defended against the accusation that if elected, he would implement huge cuts: "This idea that the Coalition is ready with a great big scalpel to slash health, to slash education, to slash jobs is simply wrong." A chi-square goodness-of-fit test found that these three functions occurred with significantly different frequencies (MP: $\chi^{2}$ $[d f=2]=48.28, p<.0001 ;$ PM: $\chi^{2}[d f=2]=114.42, \mathrm{p}<.0001$ ), confirming the first prediction (see Table 1 for these data).

Table 1. Functions of 2013 Australian Election Debates

\begin{tabular}{lccc}
\hline & Acclaims & Attacks & Defenses \\
\hline MP Debate & & & \\
Kevin Rudd (Incumbent) & $30(57 \%)$ & $18(34 \%)$ & $5(9 \%)$ \\
Bill Glasson & $15(50 \%)$ & $13(43 \%)$ & $2(7 \%)$ \\
Geoff Ebbs & $8(80 \%)$ & $2(20 \%)$ & 0 \\
Karen Hunter & $14(74 \%)$ & $5(26 \%)$ & 0 \\
Challengers & $37(63 \%)$ & $20(34 \%)$ & $2(3 \%)$ \\
Total & $67(60 \%)$ & $38(34 \%)$ & $7(6 \%)$ \\
PM Debate & & & \\
Kevin Rudd & $95(67 \%)$ & $33(23 \%)$ & $13(9 \%)$ \\
Tony Abbot & $62(58 \%)$ & $35(33 \%)$ & $9(8 \%)$ \\
Total & $157(64 \%)$ & $68(28 \%)$ & $22(9 \%)$ \\
\hline
\end{tabular}

$\mathrm{H} 2$ anticipated that candidates would discuss policy more often than character. The MP debate featured more statements on policy (68\%) than character (32\%), as did the PM debate (78\% policy and $22 \%$ character). For instance, Rudd explicitly talked about policy when he told viewers that "What I have put forward is a new policy for the future with one simple principle attached - if you're a people smuggler bringing someone to Australia and seeking to settle them in Australia, we will not allow them to be settled here." Abbot also talked about policy: "Elect a Liberal National Coalition Government and... we'll build a stronger economy so that everyone can get ahead." Rudd criticized his opponent's character: "Surely four weeks before an election he can stop being evasive." Abbott accused the Prime Minister of running an "embarrassing scare campaign," another statement about character rather than policy. So, although they 
stressed policy, the candidates discussed both topics in these debates. The frequency of these two topics was significantly different (MP: $\chi^{2}[d f=1]=12.34, p<.0005$; PM: $\left.\chi^{2}[d f=1]=71.91, \mathrm{p}<.0001\right)$. These data are displayed in Table 2.

Table 2. Topics of 2013 Australian Election Debates

\begin{tabular}{lcc}
\hline & Policy & Character \\
\hline MP Debate & & \\
Kevin Rudd & $33(69 \%)$ & $15(31 \%)$ \\
Bill Glasson & $18(64 \%)$ & $10(36 \%)$ \\
Geoff Ebbs & $6(60 \%)$ & $4(40 \%)$ \\
Karen Hunter & $14(74 \%)$ & $5(26 \%)$ \\
Total & $71(68 \%)$ & $34(32 \%)$ \\
PM Debate & & \\
Kevin Rudd & $108(84 \%)$ & $20(16 \%)$ \\
Tony Abbot & $75(77 \%)$ & $22(23 \%)$ \\
Total & $183(81 \%)$ & $42(19 \%)$ \\
\hline
\end{tabular}

Hypothesis three expected that the challenger would acclaim more, and attack less, than the incumbent. During the MP debate the challengers collectively acclaimed more, and attacked less, than the incumbent. The data from the PM debate appear to support this prediction, but they fell short of significance $\left(\chi^{2}[d f=1]=2.78, p>.09, n s\right)$ so this prediction was not supported in these debates (see Table 1). However, the fourth hypothesis, which predicted that the incumbent would acclaim more and attack less than the challenger when discussion past deeds (record in office) was upheld. The incumbent in the MP debate used past deeds to acclaim more than to attack (92\% to 8\%) whereas challengers were prone to attack more than acclaim on past deeds (93\% to 7\%). Similarly, in the PM debate, incumbent Rudd's utterances on past deeds were mostly acclaims (96\%) whereas challenger Abbott's statements about past deeds were primarily attacks (95\%). For example, the Prime Minister acclaimed his record in office in this statement:

We've helped to keep interest rates low, the lowest they've been in 60 years. We've helped also by lifting the childcare rebate from 30 to 50 per cent. We've also brought in paid parental leave, we've also got rid of Work Choices to protect fair pay and conditions, penalty rates and overtime. We've made record investments in education and record investments in health, the party that has brought you Medicare is the party has now has brought you DisabilityCare.

Low interest rate, increased childcare rebates, paid parental leave, fair labor practices, investments in education and health would be seen as positives by many voters. In contrast, Abbott, the challenger, pointed out that "It's in fact $\mathrm{Mr}$ Rudd's Government which cut $\$ 1.5$ billion out of hospital funding." Cuts is hospital funding would be seen by many as a mistake. Statistical analysis using a chi-square test of cross-classification indicated that these differences were significant (MP: $\chi^{2}[d f=1]=18.58, p<.0001, \phi=.85$; PM: $\left.\chi^{2}[d f=1]=52.8, p<.0001, \phi=.89\right)$. See Table 3 for these data.

Table 3. Forms of Policy in 2013 Australian Election Debates

\begin{tabular}{lcccccc}
\hline & \multicolumn{2}{c}{ Past Deeds } & \multicolumn{2}{c}{ Future Plans } & \multicolumn{2}{c}{ General Goals } \\
& Acclaims & Attacks & Acclaims & Attacks & Acclaims & Attacks \\
\hline MP Debate & & & & & & \\
Kevin Rudd & 11 & 1 & 1 & 2 & 6 & 12 \\
Bill Glasson & 1 & 8 & 0 & 0 & 7 & 2 \\
Geoff Ebbs & 0 & 1 & 0 & 0 & 5 & 0 \\
Karen Hunter & 0 & 4 & 0 & 0 & 10 & 0 \\
Total & 12 & 14 & 1 & 2 & 28 & 14 \\
PM Debate & & & & & & \\
Kevin Rudd & 44 & 2 & 7 & 20 & 27 & 8 \\
Tony Abbot & 1 & 19 & 25 & 3 & 26 & 1 \\
Total & 45 & 21 & 32 & 23 & 53 & 9 \\
\hline
\end{tabular}

The first Research Question investigated the distribution of policy utterances among the three forms of policy. In the first debate (MP), past deeds accounted for $37 \%$ of policy themes, future plans were $4 \%$, and general goals were $59 \%$. In the second (PM) debate, $36 \%$ of themes were about past deeds, $30 \%$ concerned future plans, and $34 \%$ were on general goals. Statistical analysis shows differences for the MP but not the PM debate (MP: $\chi^{2}[d f=2]=32.48$, $p>.0001$; PM: $\left.\chi^{2}[d f=2]=1.02, p>.6, n s\right)$. See Table 3 for these data. 
Table 4. Forms of Character in 2013 Australian Election Debates

\begin{tabular}{lcccccc}
\hline & \multicolumn{2}{c}{ Personal Qualities } & \multicolumn{2}{c}{ Leadership Ability } & \multicolumn{2}{c}{ Ideals } \\
& Acclaims & Attacks & Acclaims & Attacks & Acclaims & Attacks \\
\hline MP Debate & & & & & & \\
Kevin Rudd & 6 & 2 & 3 & 1 & 3 & 0 \\
Bill Glasson & 5 & 1 & 0 & 2 & 2 & 0 \\
Geoff Ebbs & 2 & 1 & 1 & 0 & 0 & 0 \\
Karen Hunter & 2 & 0 & 1 & 1 & 1 & 0 \\
Total & 15 & 4 & 5 & 4 & 6 & 0 \\
PM Debate & & & & & & \\
Kevin Rudd & 7 & 3 & 6 & 0 & 4 & 0 \\
Tony Abbot & 1 & 9 & 3 & 3 & 6 & 0 \\
Total & 8 & 12 & 9 & 3 & 10 & 0 \\
\hline
\end{tabular}

RQ2 concerned the distribution of character utterances among the three forms of character. Character comments in the MP debate addressed personal qualities (56\%), leadership ability (26\%), and ideals (18\%). In the PM debate most comments were about personal qualities (58\%), followed by leadership ability (23\%) and ideals (19\%). These categories were significantly different $\left(\mathrm{MP}: \chi^{2}[d f=2]=8.18, p<.05\right.$; PM: $\left.\chi^{2}[d f=2]=14.0, p<.001\right)$.

[insert Table 4 about here]

H5 anticipated that candidates would use general goals to acclaim more than to attack. Candidates for the Griffith seat acclaimed $(67 \%)$ more than they attacked $(33 \%)$ when discussion general goals. In the MP debate, the two candidates acclaimed more $(85 \%)$ than they attacked $(15 \%)$ when they talked about general goals. An instance of an acclaim on general goals occurs in this statement by the challenger, Abbott: "We'll build a stronger economy so that everyone can get ahead." This is a goal that would surely appear desirable to all. On the other hand, the incumbent (Rudd) objected to what he characterized as Abbott's end of implementing sharp budget cuts: "Economic wisdom right now lies not in cutting things to the bone - jobs, education, health - because if you do that, not only are those people going to be hurt badly." Statistical analysis using a chi-square test of cross-classification confirmed that these frequencies were significantly different $\left(\mathrm{MP}: \chi^{2}[\mathrm{df}=1]=4.02, p<.05\right.$; PM: $\left.\chi^{2}[d f=1]=29.82, p<.0001\right)$. The data are displayed in Table 4

Similarly, H6 predicted that when discussing ideals, the candidates would be prone to acclaim more than they attacked. In each debate, all ideals were acclaims. For example, Rudd offered an example of an acclaim about ideals in this theme: "We believe passionately in a fair go, and a fair go for all." No instances of attacks on ideals occurred in either debate. These data are reported in Table 5.

\section{Discussion}

The data are generally consistent the predictions of Functional Theory and past research (Benoit, 2014; with the exception of the prediction on incumbency and function). Overall, these candidates acclaimed more than they attacked and attacked more than they acclaimed. This is consistent with past research on PM debates in Australia (reported in Table 1) and in most other countries (Benoit, 2014). Acclaims have no drawbacks, attacks may damage the attacker as well as the attacked (because many voters dislike mud-slinging), and defenses have several drawbacks.

In these debates policy was more common than character. This was the case in the 2007 and 2010 Australian PM debates (Benoit \& Henson, 2007; Benoit \& Benoit-Bryan, 2014) as well as in political debates in other countries as well (Benoit, 2014). It appears as if more voters see the Prime Minister as more of a policy-maker than a role model; certainly the candidates discuss their policy more than their character.

In these debates, no significant difference emerged in the functions of the incumbent and the challenger. However, in the Australian debates of 2007 and 2010 (Benoit \& Henson, 2007; Benoit \& Benoit-Bryan, 2014) as well as in debates in other countries (Benoit, 2014), this prediction was confirmed, with incumbents acclaiming more and attacking less than challengers. Even though this contrast did not emerge in 2013, the incumbent acclaimed his record in office more (and attacked his opponents' records in office less) than the challengers. This second prediction about incumbency and function of past deeds was confirmed in the previous two Australian PM debates (Benoit \& Henson, 2007; Benoit \& Benoit-Bryan, 2014) and in other countries (Benoit, 2014). Arguably, a candidate's (or party's) record in the office sought is the best evidence of how a candidate will do if elected to that office. For this reason, both incumbents and challengers focus more on the incumbent's record. Of course, when incumbents discuss their own record, they acclaim; when challengers discuss the incumbent's record, they attack. Functional Theory does not argue that incumbents must acclaim more and attack less than challengers; it suggests that they are likely to do so. In these 2013 debates in Australia, the candidates did not conform to the prediction.

Candidates in these 2013 Australian debates discussed past deeds at about the same rate. The MP debate had less 
attention on future plans and more on general goals than the PM debate. Future plans require more time and effort to develop than general goals, so this contrast makes sense (candidates in the MP debate discussed future plans less, and general goals more, than candidates in the PM debate).

Examination of Table 4 reveals that the most common form of character utterance discussed in each debate was personal qualities, consistent with research on debates in other countries (Benoit, 2014). The second most common form of character was leadership ability and the least common was ideals.

As in research on the Australian PM debates of 2007 and 2010 (Benoit \& Henson, 2007; Benoit \& Benoit-Bryan, 2014; and in research on debates in other countries, Benoit, 2014), the candidates in these two debates used general goals and ideals more frequently in acclaims than attacks. It is easier to profess a goal (such as a stronger economy or a balanced budget), or an ideal (fairness, justice), than to attack it. However, specific future plans (means) are often easier to criticize than goals (ends). This relationship was found in all three years of debates in Australia as well as in political leaders debates in other countries (Benoit, 2014).

\section{Conclusions}

Political leaders debates are popping up all around the world. Many countries, such as Australia, have held such debates in several campaigns. The Functional Theory of Political Campaign Discourse (2007) does not attempt to encompass all aspects of debates: It does not, for example, study metaphor, evidence, or language (style). However, it does address two important components of these important campaign messages: the functions and topics of these messages. The 2013 Australian election debates examined here contributes to evidence that some features of debates transcend political and cultural differences. We also now have evidence on the functions and topics of an MP debate. Acclaims were more common than attacks and attacks were used more often than defenses. These candidates discussed policy more frequently than character. When discussing record in office, the incumbent was prone to acclaim more, and attack less, than the challenger. When discussing general goals and ideals, candidates used acclaims more often than attacks. As long as democratic forms of government rely on televised debates to inform and persuade voters, this important message form deserves careful study.

\section{References}

Baker, K. L., \& Norpoth, H. (1981). Candidates on television: The 1972 electoral debates in West Germany. Public Opinion Quarterly, 45, 329-345. http://dx.doi.org/10.1086/268668

Benoit, W. L. (2003). Topic of presidential campaign discourse and election outcome. Western Journal of Communication, 67, 97-112.

Benoit, W. L. (2006). Retrospective versus prospective statements and outcome of presidential elections. Journal of Communication, 56, 331-345. http://dx.doi.org/10.1111/j.1460-2466.2006.00022.x

Benoit, W. L. (2007). Communication in political campaigns. New York: Peter Lang.

Benoit, W. L. (2014). Political election debates: Informing voters about policy and character. Lanham, MD: Lexington Books.

Benoit, W. L., \& Benoit-Bryan, J. M. (2014). A Functional Analysis of the 2010 Australian Prime Minister debate. Journal of Argumentation in Context, 3, 153-168. http://dx.doi.org/10.1075/jaic.3.2.03ben

Benoit, W. L., \& Henson, J. R. (2007). A functional analysis of the 2006 Canadian and 2007 Australian election debates. Argumentation \& Advocacy, 44, 36-48.

Benoit, W. L., \& Wells, W. T. (1996). Candidates in conflict: Persuasive attack and defense in the 1992 presidential debates. Tuscaloosa: University of Alabama Press.

Benoit, W. L., Hansen, G. J., \& Verser, R. M. (2003). A meta-analysis of the effects of viewing U.S. presidential debates. Communication Monographs, 70, 335-350. http://dx.doi.org/10.1080/0363775032000179133

Blais, A., \& Boyer, M. M. (1996). Assessing the impact of televised debates: The case of the 1988 Canadian election. British Journal of Political Science, 26, 143-164. http://dx.doi.org/10.1017/S0007123400000405

Blais, A., \& Perrella, A. M. L. (2008). Systemic effects of televised candidates' debates. International Journal of Press/Politics 13, 451-464. http://dx.doi.org/10.1177/1940161208323548

Blais, A., Gidengil, E., Nadeau, R., \& Nevitte, N. (2003). Campaign dynamics in the 2000 Canadian election: How the leader debates salvaged the conservative party. Political Science \& Politics, 36, 45-50. http://dx.doi.org/10.1017/s1049096503001677

Blum-Kulka, S., \& Liebes, T. (2000). Peres versus Netanyahu: Television wins the debate, Israel, 1996. S. Coleman 
(Ed.), Televised election debates, International perspectives (pp. 66-91). London: Macmillan.

Blumler, J. G. (2011). Voters' responses to the Prime Minister debates: A rock of (future?) ages. In S. Coleman (Ed.), Leaders in the living room: The prime ministerial debates of 2010: Evidence, evaluation, and some recommendations (pp. 35-54). Oxford: Reuters Institute for the Study of Journalism.

Chaffee, S. H. (1978). Presidential debates: Are they helpful to voters? Communication Monographs, 49, $330-346$. http://dx.doi.org/10.1080/03637757809375978

Cohen, J. (1960). A coefficient of agreement for nominal scales. Educational and Psychological Measurement, 20, 37-46. http://dx.doi.org/10.1177/001316446002000104

Coleman, J. (Ed.). (2000). Televised election debates: International perspectives. New York: St. Martin's Press.

Coleman, S. (Ed.). (2011). Leaders in the living room: The prime ministerial debates of 2010: Evidence, evaluation, and some recommendations. Oxford: Reuters Institute for the Study of Journalism.

Faas, T., \& Maier, J. (2004). Chancellor-candidates in the 2002 televised debates. German Politics, 13, $300-316$. http://dx.doi.org/10.1080/0964400042000248214

Galasinski, D. (1998). Strategies of talking to each other: Rule breaking in Polish presidential debates. Journal of Language and Social Psychology, 17, 165-182. http://dx.doi.org/10.1177/0261927X980172002

Kaid, L. L, \& Johnston, A. (2001). Videostyle in presidential campaigns Style and content of televised political advertising. Westport, CT: Praeger.

Khang, H. (2008). A cross-cultural perspective on videostyles of presidential debates in the US and Korea. Asian Journal of Communication 18, 47-63. http://dx.doi.org/10.1080/01292980701823765

Landis, J. R., \& Koch, G. G. (1977). The measurement of observer agreement for categorical data. Biometrics, 33, 159-174. http://dx.doi.org/10.2307/2529310

Lanoue, D. J. (1991). Debates that mattered: Voters' reaction to the 1984 Canadian leadership debates. Canadian Journal of Political Science, 24, 51-65. http://dx.doi.org/10.1017/S000842390001341X

LeDuc, L., \& Price, R. (1985). Great debates: The televised leadership debates of 1979. Canadian Journal of Political Science, 18, 135-153. http://dx.doi.org/10.1017/S0008423900029255

Maier, J., \& Faas, T. (2003). The affected German voter: Televised debates, follow-up communication, and candidate evaluations. Communications, 28, 383-404. http://dx.doi.org/10.1515/comm.2003.025

Matsaganis, M., \&.Weingarten, C. (2001). The 2000 U.S. presidential debate versus the 2000 Greek prime minister debate. American Behavioral Scientist, 44, 2398-2409. http://dx.doi.org/10.1177/00027640121958393

McKinney, M. S., \& Carlin, D. B. (2004). Political campaign debates. In L. L. Kaid (Ed.), Handbook of political communication research (pp. 203-234). Mahwah, NJ: Lawrence Erlbaum.

Merritt, S. (1984). Negative political advertising: Some empirical findings. Journal of Advertising, 13, 27-38. http://dx.doi.org/10.1080/00913367.1984.10672899

Reinemann, C., \& Maurer, M. (2005). Unifying or polarizing short-term effects and postdebate consequences of different rhetorical strategies in televised debates. Journal of Communication, 55, 775-794. http://dx.doi.org/10.1111/j.1460-2466.2005.tb03022.x

Scammell, M., \& Langer, A. I. (2006) Political advertising in the United Kingdom. In L. L. Kaid \& C. Holtz-Bacha, (Eds.) The SAGE handbook of political advertising (pp. 65-82). London: Sage. http://dx.doi.org/10.4135/9781412973403.n4

Schrott, P. R. (1990). Electoral consequences of "winning” televised campaign debates. Public Opinion Quarterly, 54, 567-585. http://dx.doi.org/10.1086/269228

Stewart, C. J. (1975). Voter perception of mud-slinging in political communication. Central States Speech Journal, 26, 279-286. http://dx.doi.org/10.1080/10510977509367854

\section{$(\mathrm{cc}) \mathrm{E}_{\mathrm{Y}}$}

This work is licensed under a Creative Commons Attribution 3.0 License. 